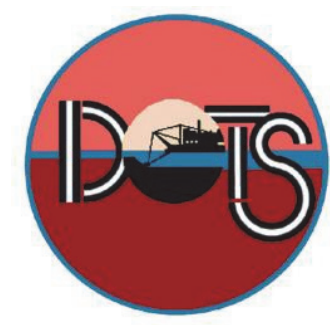

ERDC/TN DOTS-20-1

January 2020

Revised July 2021

\title{
Fate and Effects of Microcystin in Nearshore and Upland Environments: A Literature Review
}

\author{
by Andrew D. McQueen, Michael W. Habberfield, Karen G. Keil, \\ and Burton C. Suedel
}

STUDY PURPOSE: Dredged material (DM) impacted by harmful algal blooms (HABs) potentially introduces algal toxins (e.g., microcystins [MCs]) to areas where material is being stored (e.g., confined disposal facilities [CDFs]) or beneficially used for nearshore and upland placement for land and habitat improvements. The objective of this study was to conduct a literature review of the current information related to the fate and transport of MCs in upland environments. The study also focused on detailing relevant pathways for potential human exposures during, and following, relocation of DM from collection to placement sites for beneficial use.

BACKGROUND: To appropriately manage the 200-300 million cubic yards (CY) of DM collected annually in the United States (U.S.), beneficial use programs are increasingly being favored over traditional disposal practices due to the economic, social, and ecological benefits, along with the limited capacity of CDFs. However, potential risks associated with DM re-use must be evaluated prior to placement. Recently, the potential occurrence of MCs in DM sourced from HAB-impacted water bodies has raised concerns regarding the risks with upland andnearshore placement of DM. MCs are known hepatotoxins that can pose ecological and human health risks. The presence and persistence of MCs in DM have the potential to prevent the beneficial use of otherwise suitable material sourced from HAB-impacted water bodies.

APPROACH: A literature review was conducted to document what is currently known about the fate and transport of MCs in DM relocated to upland environments for beneficial use, with specific emphasis on relevant exposure pathways to human receptors. The review will also document gaps of information related to the fate of MCs in upland environments and inform future research needs. This documentation provides available information that can be used to inform the assessment and management of risks associated with MCs in upland environments.

\section{RESULTS}

Chemical and physical properties of MCs. MCs are common cyanotoxins found in waters through the world (Carmichael 1992) and are relatively stable in the aquatic environment due to their resistance to hydrolysis at near neutral pH (USEPA 2015a). Numerous genera of cyanobacteria are associated with $\mathrm{MC}$ production and are known to bloom to high densities, including Microcystis, Anabaena, Anabaenopsis, Aphanizomenon, Aphanocapsa, Dolichospermum, Nostoc, Planktothrix, and Pseudanabaena (Stewart et al. 2006; Carey et al. 
ERDC/TN DOTS-20-1

January 2020

Revised July 2021

2012; USEPA 2015b). Microcystins have a cyclic heptapeptide structure with one non-protein amino acid (ADDA; 3-amino-9-methoxy-2,6,8-trimethyl-10-phenyldeca; 4,6-dienoic acid) forming a side chain that is consistent among MC congeners, for which there are over 100 variants. Changes in two amino acids in the ring structure contribute to most of the structural variability. MC-LR (named for leucine and argenine substitutions) is the most commonly occurring congener and is the focus of much of the available MC scientific literature. Based on the chemical and physical attributes of MC-LR, these cyanotoxins are water soluble (solubility of $>1 \mathrm{~g} / \mathrm{L}$ ), nonvolatile, with relatively weak lipophilic interactions $\left(\log \mathrm{K}_{\mathrm{OW}}=-0.37\right)$ and structurally resistant to heat and hydrolysis (USEPA 2015a, b) (Table 1). Reported sediment partitioning coefficients $\left(\mathrm{K}_{\mathrm{d}}\right)$ indicate that MCs can adsorb to soils and sediments, but the extent is dependent on the soil characteristics (predominantly organic matter and clay content) (Morris et al. 2000; Miller and Fallowfield 2001; Schmidt et al. 2014). These properties influence the fate, transport, and adverse effects of MCs in aquatic and terrestrial environments.

Table 1. Physical and chemical properties of MC-LR (unless otherwise noted).

\begin{tabular}{|c|c|c|}
\hline Parameter & Characteristic & Source \\
\hline Identification & 101043-37-2 (CAS Number) & 1,2 \\
\hline Formula & $\mathrm{C}_{49} \mathrm{H}_{74} \mathrm{~N}_{10} \mathrm{O}_{12}$ & 1,2 \\
\hline Molecular weight & $995.17 \mathrm{~g} / \mathrm{mol}$ & 1,2 \\
\hline Physical State & White solid & 1 \\
\hline Water Solubility & $>1 \mathrm{~g} / \mathrm{L}$ & 3 \\
\hline Density & $1.29 \mathrm{~g} / \mathrm{cm}^{3}$ & 1,2 \\
\hline $\log \mathrm{K}_{\mathrm{ow}}$ & -0.37 (neutral $\mathrm{pH})$ & 4 \\
\hline \multicolumn{3}{|l|}{ Soil/Sedimen d } \\
\hline Sediment A $(4-8 \% \text { OM })^{*}$ & $5(\mathrm{pH}$ of 7.0$) \mathrm{ml} / \mathrm{g}$ & 4 \\
\hline Sediment B (17-21\% OM)* & $35(\mathrm{pH}$ of 7.0$) \mathrm{ml} / \mathrm{g}$ & 4 \\
\hline Soil A (2.5\% OC; 4\% clay) & $0.80(\mathrm{pH}$ of 6.7$) \mathrm{ml} / \mathrm{g}$ & 5 \\
\hline Soil B (5\% OC; 32\% clay) & $4.46(\mathrm{pH}$ of 6.7$) \mathrm{ml} / \mathrm{g}$ & 5 \\
\hline Boiling point $\left({ }^{\circ} \mathrm{C}\right)$ & Structurally resistant up to $300^{\circ} \mathrm{C}$ & 6 \\
\hline (1) NCBI (2018) & (4) Wu et al. (2011) & \\
\hline (2) TOXLINE (2018) & (5) Miller et al. (2001) & \\
\hline (3) Rivasseau et al. (1998) & (6) Wannemacher (1989) & \\
\hline$* \mathrm{MC}-\mathrm{RR}$ & & \\
\hline
\end{tabular}

Transfer of MC from water to sediment. MCs can persist in lake sediments following HAB events (Mohamed et al. 2007; Pawlik-Skowronska et al. 2010; Efting et al. 2011; Johnston et al. 2013; Song et al. 2015; Zastepa et al. 2017). MCs can transfer from the water column to the sediments by a number of pathways, including settling of cyanobacterial cells (containing MCs) from the water column to the sediments. Additionally, MCs occurring in the overlying water, or pore-water, may partition to sediments via sorption of aqueous MCs to sediment particles. Therefore, MCs in lake sediments can be distributed in the pore-water (aqueous phase), sediment particles (sorbed), or within benthic algal mats (intracellular MCs). In one study investigating the distribution of MCs in lake sediments, the pore-water generally contained higher concentrations of MCs as compared to adsorbed sediment particles (Zastepa et al. 2017). Johnston et al. (2013) 
reported concentrations of MC-LR and MC-LA measured in surficial lake sediments $(<2 \mathrm{~cm}$; measured via HPLC/MS/MS) from shallow $(<3 \mathrm{~m})$ and deep $(4-8 \mathrm{~m})$ water depths. Of the six lakes assessed, MCs were detected in sediments in all but one lake ( $>80 \%$ of sampled lakes). These observations are similar to trends observed in other lake cores, where detectable concentrations of MCs are present in both surficial sediment and sediment in deeper (older) layers (PawlikSkowronska et al. 2010; Efting et al. 2011). Several site-specific parameters have been attributed to the distribution of MCs among the sediment, pore-water, and overlying surface water, including sediment characteristics (e.g., organic matter and clay content) and MC congeners (Mohamed et al. 2007; Zastepa et al. 2017). In addition, it should also be noted that dredging methods (mechanical vs. hydraulic) and DM source (e.g., CDF or newly sourced DM) prior to beneficial use (BU) placement could influence $\mathrm{MC}$ exposure characteristics (e.g., concentration, form, etc.).

Fate and transport of MCs in upland and nearshore environments. A conceptual site model was developed based on the scenario of placement of MC-contaminated DM in an upland or nearshore beneficial use area (e.g., agricultural land, beach nourishment) (Figure 1). Possible sources of DM-MC contamination include aqueous MCs (in DM pore-water), cell-bound MCs (in viable and non-viable algal cells), and sediment associated MCs (sorbed to DM). It should be noted that each of these sources influence the fate and effects of MCs in upland environments.

Microbial degradation. Aerobic and anaerobic microbial degradation is a predominant mechanism for the transformation of MCs in upland soils, with degradation half-lives ranging from 2 to 18 days (Miller and Fallowfield 2001; Chen et al. 2006). Several microbial genera that reside in soils are known degraders of MCs, including Arthrobacter sp., Brevibacterium sp., and Rhodococus sp. (Manage et al. 2009). The rate and extent of microbial degradation is a function of the environmental conditions (e.g., temperature, nutrient content, microbial diversity and densities) (Chen et al. 2010). In a study investigating the microbial degradation of MCs in water using lake sediment as an inoculum, initial $\mathrm{MC}$ concentrations of $5 \mathrm{mg} / \mathrm{L}$ declined to nondetectable concentrations within two days (Chen et al. 2010). In another microbial degradation study of MCs in sediment, Holst et al. (2003) achieved degradation of MC (aqueous phase) from $100 \mathrm{mg} / \mathrm{L}$ to $<20 \mathrm{mg} / \mathrm{L}$ within one day with the use of nutrient (nitrate) additions to promote microbial growth. There is ancillary evidence to suggest intracellular MCs (i.e., cell-bound) may have slower microbial degradation rates than extra-cellular (i.e., aqueous phase). For example, microcystin "scums" dried and left on beaches retained high concentrations of MCs for months (Jones et al. 1995). Additionally, dried and stored specimens of cyanobacteria in ambient temperatures are known to contain MCs that are stable for decades (Metcalf et al. 2012a). To date (as of 2020), the influence of MC sorption to soil/sediment particles on microbial degradation rates is currently unknown. Results in the peer-reviewed literature indicate that microbial degradation is likely the dominate fate process for MCs in nearshore or upland environments, with MC degradation occurring relatively rapidly (days to weeks) (Miller and Fallowfield 2001; Chen et al. 2006). However, the rate and extent of microbial degradation is dependent on the form of MCs (cell-bound, aqueous, particle-bound) and environmental conditions present (e.g., microbial density and diversity, temperature, nutrient content). 
ERDC/TN DOTS-20-1

January 2020

Revised July 2021

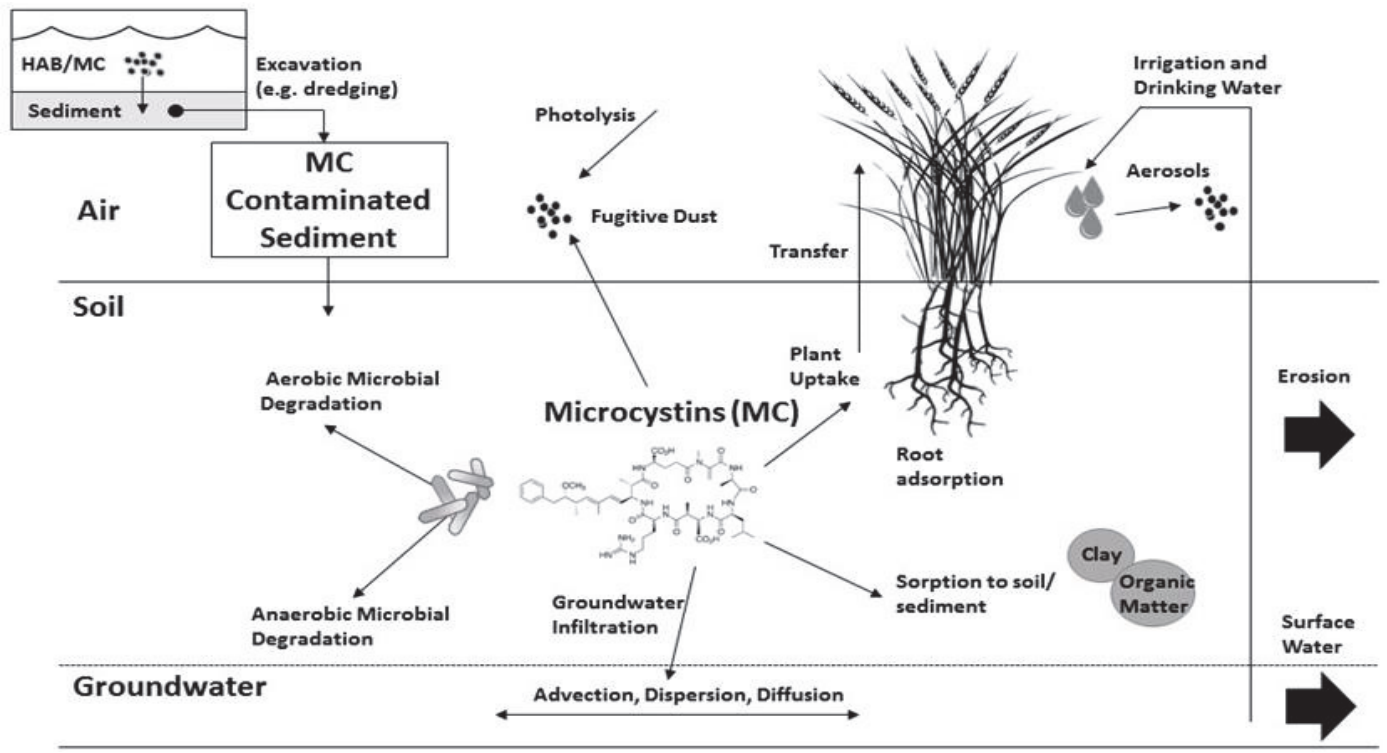

Figure 1. Conceptual site model of $M C$ transfer and transformation processes in nearshore or upland environments.

Mobility of MCs in soils and groundwater infiltration. Due to the relatively high solubility of MCs (solubility > 1 g/L), and low Kow $(-0.37$; MC-LR), there is evidence to support that aqueous transport in the soil is an important transfer mechanism. The rate and extent of adsorption of MCs are dependent on soil type and environmental conditions (e.g., MC sorption decreases with increasing pH) (Miller et al. 2001; Wu et al. 2011); however, in general, MCs soiladsorption is $<20 \%$ (Miller and Fallowfield 2001; Chen et al. 2006; Corbel et al. 2014a,b ;Corbel et al. 2016). Clay and organic carbon content in soils influence the rate and extent of MC transfers. Soils with a greater clay and organic carbon content were capable of adsorbing higher concentrations of MCs as compared to sandy, low organic content soils (Morris et al. 2000; Miller et al. 2001; Miller and Fallowfield 2001). In one study using sandy sediment ( $76 \%$ sand, $13 \%$ silt; $11 \%$ clay), less than 14\% of the MC-LR was adsorbed to soil particles (Corbel et al. 2014a). MC-LR soil adsorption from aqueous phase can be relatively rapid, with half-lives ofsoil adsorption ranging from 0.02 to 0.35 days (Miller and Fallowfield 2001). MCs adsorption to soils likely involve complex interactions (i.e., cation bridging, hydrogen bonding, and electrostatic interactions), in which, OM plays a critical role (Wu et al. 2011). It should be noted that adsorption may influence the bioavailability of MCs; however, the role of altered toxicity associated with soil and tissue activity (e.g., adsorption, covalent bonding, etc.) is largely unknown (Bouaicha and Corbel 2016). In terms of potential groundwater infiltration, MCs have been detected in drinking water wells near surface waters containing toxin producing blooms (Yang et al. 2016) and in shallow groundwater near areas where mechanically harvested algal blooms were placed (Chen et al. 2012). In Lake Chaohu, China, Yang et al. (2016) observed positive spatial and temporal relationships of MCs occurring in surface waters and nearby well water sources. Furthermore, leachate studies on various soil types and MC congeners indicated that MCs were mobile in soils, with leachate recoveries ranging from $9-73 \%$ of MC-LR (Chen etal. 2006). In a risk assessment of the potential use of harvested cyanobacterial blooms as plant fertilizers, Chen et al. (2006) concluded MCs may be persistent in Chinese agricultural soils and potentially leach to groundwater during rainy seasons. Future research needs include the evaluation of the potential 
rate and extent to which MCs leached from soils/sediments can infiltrate groundwater.

Transfer of MCs from irrigation water to plants and animals. Once MCs reach groundwater and/or surface water resources via leaching from the upland-applied MCcontaminated DM, the scientific literature indicates that MCs can transfer from water and accumulate in plants (Codd et al. 1999; Peuthert et al. 2007; Crush et al. 2008; Chen et al. 2012; Lee et al. 2017a), fish (Xi et al. 2007; Martins and Vasconcelos 2009), and invertebrates (bivalves, crustaceans, and gastropods) Kotak et al. 1996; Chen and Xi 2005; Xi et al. 2007; Gutierrez-Praena et al. 2013). No peer-reviewed studies were found evaluating the transfer of MCs from dry soils directly; however, plant and animal uptake studies are limited to MC- contaminated water.

Aerosols and fugitive dust. When present in surface water, aerosolized MCs have been documented emanating from wave and wind energy, which disperse MCs into air with water droplets (Cheng et al. 2007; Backer et al. 2008; Funari and Testai 2008; Wood and Dietrich 2011). From MC-contaminated desert sand, MCs have also been documented in cyanobacterial desert crusts in arid environments (Metcalf et al. 2012b), with concentrations ranging from 1.5-53.7 ng $\mathrm{MC} / \mathrm{g}$ (between 2 and $56 \mu \mathrm{g} / \mathrm{m}^{2}$ ).

Photolysis. Photolysis of MCs in DM placed in nearshore or upland environments are anticipated to be limited to surficial or fugitive dust and surface or irrigation water discharges, as sunlight exposure is minimal for MC in the benthic phase and absent for any subsurface DM placements. Aqueous MC-LR photolysis rates range from days to weeks, are dependent on the exposure of solar energy (i.e., ultra-violet intensity), and can be increased by the presence of photosensitizers such as humic substances (Welker and Steinberg 2000; Wormer et al. 2010) and phycobiliproteins (USEPA 2015b).

\section{POTENTIAL HUMAN HEALTH RISKS}

Mechanism of MC toxicity. MCs primary mechanism of action occurs in hapatocytes (liver cells), and to some extent kidney cells (Feurstein et al. 2009). MCs can be actively transported across cell membranes by specific organic anionic transporting polypeptides (OATPs) (Carmichael, 1994). Once inside cells, MCs bind with protein phosphatases and inhibit their cellular activity, which disrupts the regulation of phosphate groups on proteins. This disruption alters the protein filaments that form the structure of hepatocytes, causing a cascade of effects leading to breakdown of the cellular structure, blood accumulation, tissue damage, and hemorrhagic shock (Carmichael 1994). Based on the mechanisms of MC toxicity, the principle studies used for developing drinking water provisional guidelines predominantly relied on liver effects endpoints (WHO 2003b and USEPA 2015b). There is evidence that MCs can be transported across the blood-brain barrier (Feurstein et al. 2009); however, molecular mechanisms of neurotoxic effects remain largely unknown (Hu et al. 2016). It should be noted that changing the structure of MC molecules can potentially change the affinity to, and inhibitionof, the target active sites (i.e., covalent modification on protein phosphatases) (Hitzfeld et al. 2000). However, the role in soil-particle binding activity to the structure of MCs and the potential biotransformation (e.g., covalent binding) of MCs in plant tissues and the subsequent effects on bioavailability and toxicity of MCs is largely unknown (Bouaicha and Corbel 2016). 
ERDC/TN DOTS-20-1

January 2020

Revised July 2021

Potential exposure routes and adverse effects of MCs. Potential human exposure routes of MCs were considered based on the following two scenarios: (1) DM in a CDF (Figure 2) and, (2) DM placed in upland and nearshore environments (Figure 3). Relatively limited peer- reviewed information was found for either scenario of environmental exposures of MCs to humans. It should be noted that the vast majority of data available for MC-related human health risks are related to pathways in water (i.e., recreation or drinking-water exposures). Nevertheless,potential risks of $\mathrm{MC}$ toxicity (e.g., anticipated dominant pathways, laboratory-derived effects thresholds, etc.) are discussed below.

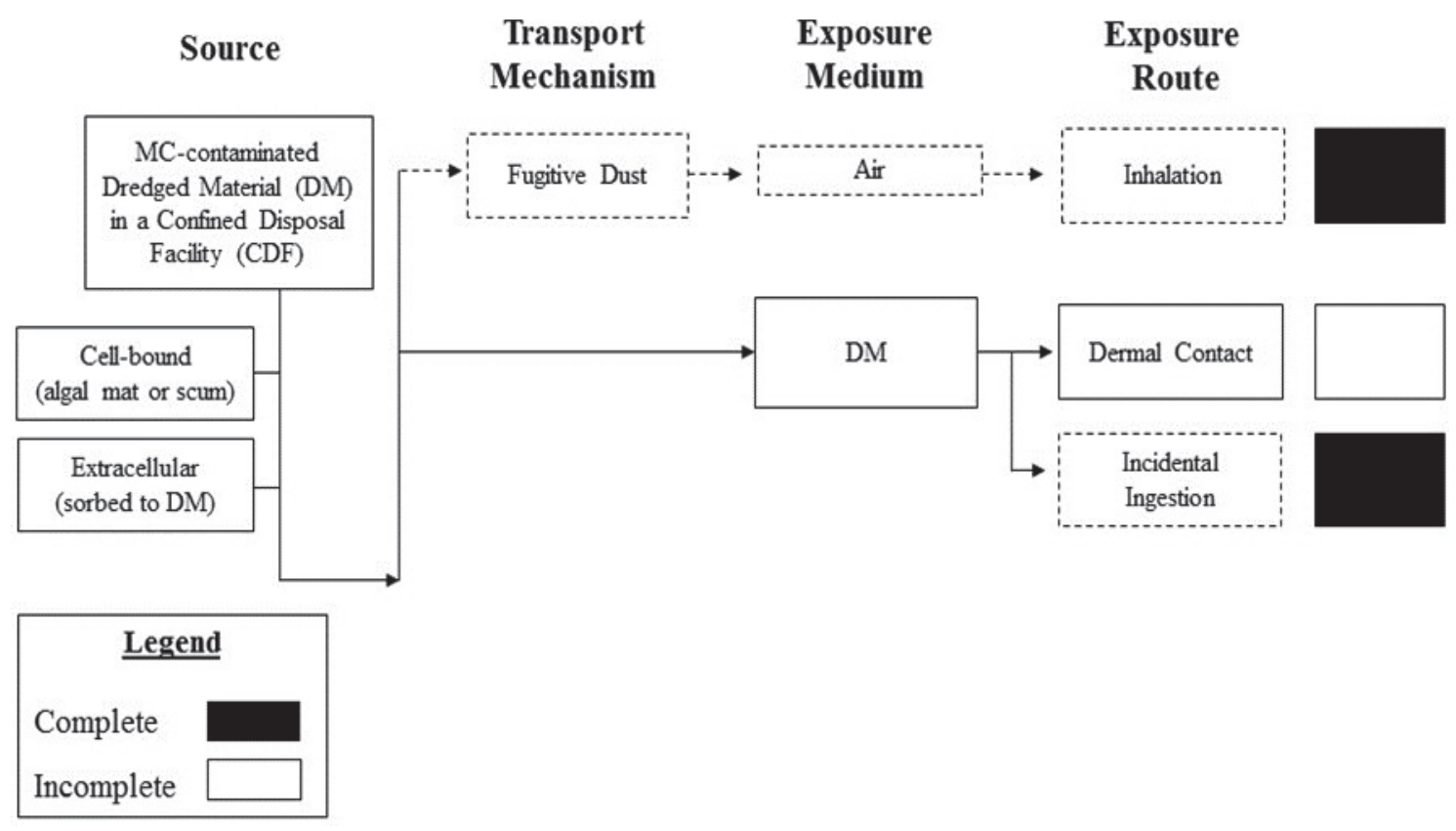

Figure 2. Potential sources, transport mechanisms, media, and exposure routes of MC-contaminated DM located in a CDF for human receptors. Note: Dashed lines indicate limited data are available for a given exposure pathway. 


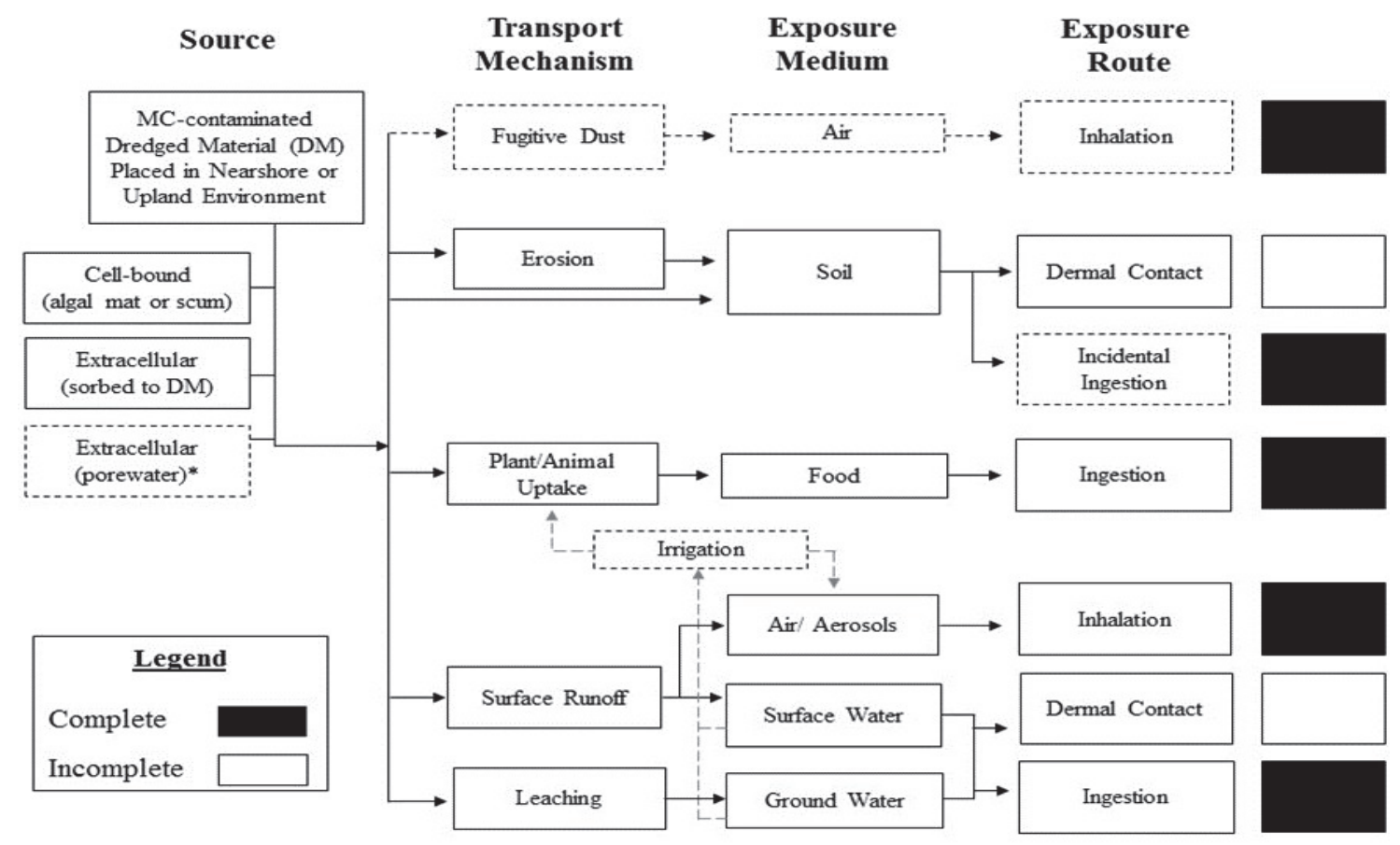

*Porewater MCs are likely dependent on origin and placement method of DM (e.g. confined disposal facility versus newly dredged)

Figure 3. Potential sources, transport mechanisms, media, and exposure routes of nearshore and upland placement of MC-contaminated DM for human receptors. Note: Dashed lines indicate limited data are available for a given exposure pathway.

Incidental ingestion of MC-contaminated DM (e.g., soil). As presented in Figures 2 and 3 , incidental ingestion of the MC-contaminated soil may be a mechanism of exposure. However, there are many unknowns regarding this potential exposure route. For example, the bioavailability and associated toxicity of MCs adsorbed to a solid matrix is largely unknown. Additionally, the current lack of standardized methods for quantification of MCs in solid matrices also confound the potential risks associated with contaminated soils.

Drinking water and digestive routes. Secondary routes of exposure and subsequent potential ingestion risk of MCs in nearshore or upland environments is dependent on the migration of placed MCs in DM to surface or groundwater and/or transfers to edible plants or animals. If MC can migrate from upland-placed DM to groundwater, or back into surface water bodies used as drinking water resources, human-health risks associated with MC-contaminated drinking water may be characterized using previous evaluations provided by the World Health Organization (WHO) (2003a) and the U. S. Environmental Protection Agency (USEPA) (2015a).WHO (2003a) proposed a provisional drinking water guideline for MC-LR of $1.0 \mu \mathrm{g} / \mathrm{L}$. USEPA (2015a) developed provisional drinking water guidelines for MC-LR which applies to short-term (10-day) exposures with a threshold of $0.3 \mu \mathrm{g} / \mathrm{L}$ for bottle-fed infants and $1.6 \mu \mathrm{g} / \mathrm{L}$ for children and adults.

MC-contaminated food (plants or animals) is an additional exposure route to consider. GutierrezPraena et al. (2013) conducted a review of occurrences of MCs bioaccumulation in edible food and concluded that MCs can bioaccumulate in a wide range of aquatic biota and can occur at concentrations above the WHO tolerable daily intake guideline of $0.04 \mu \mathrm{g} / \mathrm{kg} \mathrm{BW}$ (Schmidt et al. 
ERDC/TN DOTS-20-1

January 2020

Revised July 2021

2014). More recently, Lee et al. (2017a) found that plants irrigated with MC-contaminated water (up to $10 \mu \mathrm{g} / \mathrm{L}$ ) contained a concentration-dependent increase of $\mathrm{MC}$ in common food crops (i.e., lettuce, carrots, and green beans). Based on the concentrations of MCs in the edible fractions of plants, the calculated human exposures exceeded both chronic reference dose $(0.003 \mu \mathrm{g} / \mathrm{kg}$ body weight) and total daily intake guidelines $(0.04 \mu \mathrm{g} / \mathrm{kg}$ body weight) (Lee et al. 2017a). Due to the heat stability of MCs, cooking the food prior to consumption may not alter the exposures (Gutierrez-Praena et al. 2013).

Significant information gaps exist to predict the potential exposure factors from MC- contaminated DM (e.g., concentrations, durations, frequency of exposures). Transfer rates or extents of MC sourced from contaminated soils to groundwater and surface waters are currently unknown. The potential rate or extent of transfer of MCs to drinking water or edible plants or animals are likely influenced by a variety of site-specific factors (e.g., form of MCs [cellular or aqueous] and environmental conditions).

Inhalation. Inhalation of MCs can potentially occur from fugitive dust emanating from dry soils (Metcalf et al. 2012b). In arid environments, there is a growing awareness of the potential airborne exposures of cyanotoxins via dust/dry soil (Metcalf et al. 2012b; Richer et al. 2015). A preliminary inhalation dust tolerable daily intake concentration for MC was estimated by Metcalfet al. (2012b) based on the laboratory-derived no-adverse-effect dose of $3 \mu \mathrm{g} \mathrm{MC} / \mathrm{kg}$ bw (as reported in Benson et al. 2005). The authors applied a 3,000-fold safety factor (based on intra- and interspecies variability, less than lifetime exposure, and potential tumor promoter) to the no- adverse-effect dose, arriving at a tolerable daily intake estimate of $0.001 \mu \mathrm{g} \mathrm{MC} / \mathrm{kg} \mathrm{BW}$ or $5-10 \mathrm{pg} \mathrm{MC} / \mathrm{L}$ air. Relevant human exposure concentrations of $\mathrm{MCs}$ in fugitive dust or aerosols from $\mathrm{MC}$ contaminated DM are currently unknown. Additionally, the bioavailability of MCs bound to soil particles is unknown.

In terms of human health inhalation risks to water droplets/aerosols of MCs, data derived from laboratory-based experiments indicate that potential adverse effects from airborne exposures of MCs are related to necrosis or inflammation of respiratory epithelial cells (Benson et al. 2005). Benson et al. (2005) exposed mice to aerosols containing 260-265 $\mu \mathrm{g} / \mathrm{m}^{3}$ of MC-LR for a duration of up to 2 hours per day, for seven consecutive days. Responses to the exposures included lesions in the nasal cavity (i.e., cellular necrosis, inflammation, degeneration, or atrophy), with a positive relationship between severity and length of lesions and duration of dailyexposure period (Benson et al. 2005). The no-adverse-effect dose for the nasal lesions was approximately $3 \mu \mathrm{g} \mathrm{MC}-\mathrm{LR} / \mathrm{kg}$ BW (Benson et al. 2005). Higher, acute respiratory doses of MC-LR can lead to systemic uptake in mice, resulting in liver effects and death, with a reported $\mathrm{LC}_{50}$ of $18 \mathrm{mg} / \mathrm{m}^{3}$ (and estimate deposited dose of $45 \mu \mathrm{g} / \mathrm{kg} \mathrm{BW}$ ) for a 10-minute exposure period (Creasia 1990).

Of one of the few field inhalation monitoring studies available for aerosolized MCs, Backer et al. (2008) evaluated the recreational exposures of humans to MCs via water-based recreation.Ninetyseven people were monitored following recreational exposures in waters containing up to $10 \mu \mathrm{g}$ $\mathrm{MC} / \mathrm{L}$ in surface water. Participants were monitored for MCs in nasal mucus and blood samples, in addition to illnesses following recreational activities. In all the participants, there were no detectable MCs in the blood samples or nasal mucus. There were no apparent airborne exposures to aerosolized $\mathrm{MCs}$, as the air samples collected from boats and personal sampling devises were below the analytical detection limit $\left(<0.1 \mathrm{ng} \mathrm{MC} / \mathrm{m}^{3}\right)$ (Backer et al. 2008). 
Dermal contact. MCs are relatively large compounds ( 1,000 daltons $)$ and do not readily passively transport across cell membranes (Eriksson et al. 1990; WHO 2003b). De Maagd et al. (1999) concluded that at near neutral $\mathrm{pH}$ (6-9), minimal passive uptake of MC-LR by organisms is anticipated, due to the lack of sorption potential (to organisms) for these compounds. These observations further support the role in active transport via OATPs necessary for the transport of MCs across cell membranes. Direct dermal and eye contact with cyanobacterial cells have been associated with allergic reactions (e.g., skin rashes, mouth sores, eye irritation) (Hunter 1998; Funari and Testai 2008); however, direct correlations between MC concentrations and dermal responses have not been reported. To evaluate dermal responses to MCs and cyanobacterial cells producing MCs, laboratory sensitization tests on guinea pigs were conducted using pure MC-LR and also cyanobacterial cells of Microcystin species (Torokne et al. 2001). Even at high MC-LR exposure concentrations of $1,500 \mathrm{mg} / \mathrm{L}$ ( $\sim 6$ orders of magnitude greater than provisional drinking water guidelines), only slightly allergenic responses were measured (affected $22 \%$ of animals tested) (Torokne et al. 2001). In terms of dermal reactions to cyanobacterial cells (e.g., Microcystin spp.; Anabaena spp.; Cylindrospermopsis raciborskii), exposures resulted in negligible to slight skin irritation and positive eye irritation (Torokne et al. 2001). Based on the current scientific literature, dermal routes of MC exposure are anticipated to be minimal. Adverse dermal effects from contact with cyanobacterial cells are generally limited to eye or skinirritation or sensitivities. Guidelines for recreational contact exposures have been proposed for cyanobacterial cell densities in aqueous phase, with "moderate probability of acute health effects" to exposures of $>20,000$ cells/mL, or $>10 \mu \mathrm{g}$ MC-LR/L (WHO 2003a). Relevant exposure concentrations of MCs in DM relevant to dermal exposures are currently unknown.

Tumor promotion and cancer risks. The International Agency for Research on Cancer (IARC) concluded that there was insufficient human and animal-based evidence for the determination of carcinogenicity of MCs; however, it is recognized that a risk of tumor promotion exist (IARC 2010). Therefore, MC-LR is classified by IARC (2006) as possibly carcinogenic to humans (Group 2B). The USEPA (2015b) health effects support document concluded that there is not enough information to support classifying MCs as a carcinogen. Based on the insufficient peer-reviewed chronic, and especially carcinogenicity data for MCs, additional studies are needed (Chen et al. 2018).

Analytical detection challenges. Common methods for detection of MCs include quantifying "total" MC concentrations using structure-based assays (e.g., enzyme-linked immunosorbent assay (ELISA)) or defining individual congeners using a combination of liquid chromatography and mass spectrometry (e.g., HPLC/MS/MS). To date, methods for the detection of MCs from soil or sediment matrices have not been standardized. There are a numberof potential interferences and false-positives associated with the current MC extraction and detection methods for both soil and tissue matrices (Schmidt et al. 2014; Lee et al. 2017b); therefore, there are research needs to validate sediment and tissue $\mathrm{MC}$ detection methods and to improve the assessment of MC risk in sediment. 
ERDC/TN DOTS-20-1

January 2020

Revised July 2021

MC impacts on BU of DM in nearshore and upland environments. To date (as of 2019), there are limited peer-reviewed data indicating potential exposures of MCs from DM beneficially used in terrestrial environments. Predominate transfer and transformation pathways of MCs in soils include microbial degradation, aqueous transfers (e.g., hydraulic mobility in soils), and biotic uptake. Potential routes of MC exposures to humans in upland environments include ingestion and inhalation, while dermal contact is estimated to be a minor (or incomplete) pathway. However, based on existing published studies reporting relevant exposure factors (i.e., concentration, duration, forms, etc.) of MCs in sediments, adverse effects of MCs in DM used beneficially in upland environments to either ecological or human receptors are largely unknown at this time.

DATA GAPS AND TOPIC AREAS FOR FUTURE RESEARCH: There are several current data gaps with regards to evaluating risks of MCs in sediments in general and DM in particular. Examples of these data gaps include the following:

- Standard laboratory methods for quantifying MC in a solid matrix (e.g., DM) to reduce false positive results,

- Persistence, bioavailability, and degradation processes of MC in DM with varying characteristics (e.g., grain size and organic content), process methods (e.g., dewatering and handling/storage time), and source areas (e.g., newly dredged vs. CDF),

- Plant uptake of MC directly from upland soil rather than from irrigation water,

- Influence of sorption of MCs to soil/sediment particles to bioavailability, and

- Aerosolization of microcystin from a solid matrix (e.g., beach sand or upland soil), subsequent transport, and resultant concentrations associated with inhalation risk to human receptors.

ACKNOWLEDGMENTS: Funding was provided by the U. S. Army Corps of Engineers (USACE) Buffalo District and the Dredging Operations Technical Support (DOTS) Program, Dr. Burton Suedel, program manager. Technical reviews were provided by Dr. Kaytee Pokrzywinski and Dr. Victor Medina, both of the Engineer Research and Development Center-Environmental Laboratory (ERDC-EL).

POINTS OF CONTACT: This technical note (TN) was prepared as part of the Dredging Operations Technical Support (DOTS) Program and was written by Dr. Andrew McQueen, Andrew.D.McQueen@usace.army.mil) of the U.S. Army Engineer Research and Development Center (ERDC), Environmental Laboratory (EL); Dr. Michael Habberfield; Michael.W.Habberfield@usace.army.mil),Dr. Karen G. Keil (Karen.G.Keil@usace.army.mil), and Dr. Burton C. Suedel (Burton.Suedel@usace.army.mil). For information about DOTS, please contact the DOTS Program Manager, Dr. Burton C. Suedel at (Burton.Suedel@usace.army.mil).

This technical note should be cited as follows:

McQueen, A. D., M. W. Habberfield, K. G. Keil, and B. C. Suedel. Revised 2021. Fateand Effects of Microcystin in Nearshore and Upland Environments: A Literature Review. DOTS Technical Notes Collection. ERDC TN-DOTS-20-1. Vicksburg, MS: U.S. Army Engineer Research and Development Center. 
Backer, L. C., W. Carmichael, B. Kirkpatrick, C. Williams, M. Irvin, Y. Zhou, T. B. Johnson, K. Nierenberg, V. R. Hill, S. M. Kieszak, and Y. S. Cheng. 2008. Recreational exposure to low concentrations of microcystins during an algal bloom in a small lake. Marine Drugs 6(2):389-406. https://doi.org/10.3390/md6020389.

Benson, J. M., J. A. Hutt, K. Rein, S. E. Boggs, E. B. Barr, and L. E. Fleming. 2005. The toxicity of microcystin LR in mice following 7 days of inhalation exposure. Toxicon 45(6): 691-698. doi: 10.1016/j.toxicon.2005.01.004.

Bouaicha, N., and S. Corbel. 2016. Cyanobacterial toxins emerging contaminants in soils: A review of sources, fate, and impacts on ecosystems, plants and animal and human health. In Technology Soil Contamination - Current Consequences and Further Solutions. http://www.intechopen.com/books/soil-contamination-currentconsequences-and-further-solutions.

Carmichael, W. W. 1992. A Status Report on Planktonic Cyanobacteria (Blue Green Algae) and their Toxins. EPA/600/R-92/079. Cincinnati, OH: Environmental Monitoring Systems Laboratory, Office of Research and Development, U.S. Environmental Protection Agency.

Carmichael, W. W. 1994. The toxins of cyanobacteria. Scientific American 270(1):78-86. https://www.jstor.org/stable/24942554.

Carey, C. C., B. W. Ibelings, E. P. Hoffmann, D. P. Hamilton, and J. D. Brookes. 2012. Eco-physiological adaptations that favour freshwater cyanobacteria in a changing climate.Water research 46(5):1394-1407. https://doi.org/10.1016/j.watres.2011.12.016.

Chen, J., F. X. Han, F. Wanga, H. Zhang, and Z. Shi, Z. 2012. Accumulation and phytotoxicity of microcystin-LR in rice (Oryza sativa). Ecotoxicology and Environmental Safety 76: 193-199. https://doi.org/10.1016/j.ecoenv.2011.09.022.

Chen, J., and P. Xie. 2005. Seasonal dynamics of the hepatotoxic microcystins in various organs of four freshwater bivalves from the large eutrophic lake Taihu of subtropical China and the risk to human consumption. Environmental Toxicology 20(6):572-584. https://doi.org/10.1002/tox.20146|.

Chen, L., J. P. Giesy, and P. Xie. 2018. The dose makes the poison. Science of the Total Environment 621: 649-663. https://doi.org/10.1016/j.scitotenv.2017.11.218.

Chen, W., Y. Jia, E. Li, S. Zhao, and Q. Zhou. 2012. Soil-based treatments of mechanically collected cyanobacterial blooms from Lake Taihu: efficiencies and potential risks. Environmental Science and Technology 46(24):1337013376.

Chen, W., L. Song, N. Gan, and L. Li. 2006. Sorption, degradation and mobility of microcystins in Chinese agriculture soils: Risk assessment for groundwater protection. Environmental Pollution 144(3):752-758. https://doi.org/10.1016/j.envpol.2006.02.023.

Chen, X., X. Yang, L. Yang, B. Xiao, X. Wu, J. Wang, and H. Wan, H. 2010. An effective pathway for the removal of microcystin LR via anoxic biodegradation in lake sediments. Water Research 44(6):1884-1892. https://doi.org/10.1016/j.watres.2009.11.025.

Cheng, Y. S., Y. Zhou, M. Irvin, B. Kirkpatrick, and L. C. Backer. 2007. Characterization of aerosols containing microcystin. Marine Drugs 5:136-150. https://doi.org/10.3390/md504136.

Codd, G., S. Bell, K. Kaya, C. Ward, K. Beattie, and J. Metcalf, J. 1999. Cyanobacterial toxins, exposure routes and human health. European Journal of Phycology 34:405-415.

Corbel, S., N. Bouaicha, and C. Mougin. 2014a. Dynamics of the toxic cyanobacterial microcystin-leucineargininepeptide in agricultural soil. Environmental Chemistry Letters 12(4):535-541.

Corbel, S., M. Christian, and N. Bouaicha. 2014b. Cyanobacterial toxins: Modes of actions, fate in aquatic and soil ecosystems, phytotoxicity and bioaccumulation in agricultural crops. Chemosphere 96:1-15. https://doi.org/10.1016/j.chemosphere.2013.07.056.

Corbel, S., C. Mougin, S. Nelieu, G. Delarue, and D. Bouaicha. 2016. Evaluation of the transfer and the accumulation of microcystins in tomato (Solanum lycopersicum cultivar MicroTom) tissues using a cyanobacterial extract containing microcystins and the radiolabeled microcystin-LR (14C-MC-LR). Science of the Total Environment 


\section{ERDC/TN DOTS-20-1}

January 2020

Revised July 2021

541:1052-1058. https://doi.org/10.1016/j.scitotenv.2015.10.004.

Creasia, D. A. 1990. Acute inhalation toxicity of microcystin-LR with mice. Toxicon 28(6):605.

Crush, J. R.,L. R. Briggs, J. M. Sprosen, and S. N. Nichols. 2008. Effect of irrigation with lake water containing microcystins on microcystin content and growth of ryegrass, clover, rape, and lettuce. Environmental Toxicology. 23:246-252. https://doi.org/10.1002/tox.20331.|

de Maagd, P. G. J., A. J. Hendriks, W. Seinen, and D. T. Sijm. 1999. pH-dependent hydrophobicity of the cyanobacteria toxin microcystin-LR. Water Research 33(3):677-680. https://doi.org/10.1016/S0043$\underline{1354(98) 00258-9 .}$.

Efting, A. A., D. D. Snow, and S. C. Fritz. 2011. Cyanobacteria and microcystin in the Nebraska (USA) Sand Hills Lakes before and after modern agriculture. Journal of Paleolimnology 46(1):17-27.

Eriksson, J. E., L. Grönberg, S. Nygård, J. P. Slotte, and J. A. Meriluoto. 1990. Hepatocellular uptake of 3Hdihydromicrocystin-LR, a cyclic peptide toxin. Biochimica et Biophysica Acta (BBA)-Biomembranes 1025(1):6066. https://doi.org/10.1016/0005-2736(90)90190-Y.

Feurstein, D., K. Holst, A. Fischer, and D. R. Dietrich. 2009. Oatp-associated uptake and toxicity of micocystins in primary murine whole brain cells. Toxicology and Applied Pharmacology 234(2):247-255. https://doi.org/10.1016/j.taap.2008.10.011.

Funari, E., and E. Testai. 2008. Human health risk assessment related to cyanotoxins exposure. Critical Reviews in Toxicology 38(2): 97-125. https://doi.org/10.1080/10408440701749454.

Gutierrez-Praena, D., A. Jos, S. Pichardo, I. M. Moreno, and A. M. Camean. 2013. Presence and bioaccumulation of microcystins and cylindrospermopsin in food and the effectiveness of some cooking techniques at decreasing their concentrations: A review. Food and Chemical Toxicology 53:139-152. https://doi.org/10.1016/j.fct.2012.10.062.

Hitzfeld, B. C., S. J. Hoger, and D. R. Dietrich. 2000. Cyanonbacterial toxins: Removal during drinking water treatment, and human risk assessment. Environmental Health Perspectives 108:113-122. https://doi.org/10.1289/ehp.00108s1113.

Holst, T., N. O. G. Jørgensen, C. Jørgensen, and A. Johansen. 2003. Degradation of microcystin in sediments at oxic and anoxic, denitrifying conditions. Water Research 37(19):4748-4760. https://doi.org/10.1016/S0043$\underline{1354(03) 00413-5 .}$.

Hunter, P. R. 1998. Cyanobacterial toxins and human health. Journal of Applied Microbiology 84(1):35-40.

Hu, Y., J. Chen, H. Fan, P. Xie, and J. He. 2016. A review of neurotoxicity of microcystins. Environmental Science and Pollution Research 23(8):7211-7219.

IARC (International Agency for Research on Cancer). 2010. IARC Monographs on the evaluation of carcinogenic risks to humans, ingested nitrate and nitrite and cyanobacterial peptide. Toxins 94.

Johnson, J., M. Friese, and R. Coots. 2013. Microcystins and other blue-green algae toxins analyzed in fish and sediment from Washington lakes. \#13-03-001. Olympia, WA: Environmental Assessment Program. Washington State Department of Ecology.

Jones, G. J., I. R. Falconer, and R. M. Wilkins. 1995. Persistence of cyclic peptide toxins in dried Microcystis aeruginosa crusts from Lake Mokoan, Australia. Environmental Toxicology 10(1):19-24. https://doi.org/10.1002/tox.2530100104.

Kotak, B. G., R. W. Zurawell, E. E. Prepas, and C. F. B. Holmes. 1996. Microcystin-LR concentration in aquatic food web compartments from lakes of varying trophic status. Canadian Journal of Fisheries and Aquatic Science. 53:1974-1985.

Lee., J., L. Seungjun, and X. Jiang. 2017b. Cyanobacterial toxins in freshwater and food: Important sources of exposure to humans. Annual Review of Food Science and Technology 8:281-304. https://doi.org/10.1146/annurev-food-030216-030116.

Lee, S., X. Jiang, M. Manubolu, K. Riedl, S. A. Ludsin, J. F. Martin, and J. Lee. 2017a. Fresh produce and their soils accumulate cyanotoxins from irrigation water: Implication for public health and food security. Food Research 
Manage P. M., C. Edwards, B. K. Singh, and L. A. Lawton. 2009. Isolation and identification of novel microcystindegrading bacteria. Applied Environmental Microbiology 75:6924-6928. doi: 10.1128/AEM.01928-09.

Martins, J. C., and V. M. Vasconcelos. 2009. Microcystin dynamics in aquatic organisms. Journal of Toxicology and Environmental Health, Part B 12(1):65-82. https://doi.org/10.1080/10937400802545151.

Metcalf, J. S., K. A. Beattie, E. L. Purdie, J. A. Bryant, L. M. Irvine, and G. A. Codd. 2012a. Analysis of microcystins and microcystin genes in 60-170-year-old dried herbarium specimens of cyanobacteria. Harmful algae 15:4752. https://doi.org/10.1016/j.hal.2011.11.004.

Metcalf, J. S., R. Richer, P. A. Cox, and G. A. Codd. 2012b. Cyanotoxins in desert environments may present a risk to human health. Science of the Total Environment 421-422:118-123. https://doi.org/10.1016/j.scitotenv.2012.01.053.

Miller, M. J., M. M. Critchley, J. Hutson, and H. J. Fallowfield. 2001. The adsorption of cyanobacterial hepatotoxins from water onto soil during batch experiments. Water Research 35(6):1461-1468. https://doi.org/10.1016/S00431354(00)00419-X.

Miller, M. J., and H. J. Fallowfield. 2001. Degradation of cyanobacterial hepatotoxins in batch experiments. Water Science and Technology 43(12):229-232. https://doi.org/10.2166/wst.2001.0745.

Mohamed, Z. A., M. H. El-Sharouny, and W. S. Ali. 2007. Microcystin concentrations in the Nile River sediments and removal of microcystin-LR by sediments during batch experiments.Archives of environmental contamination and toxicology 52(4):489.

Morris, R. J., D. E. Williams, H. A. Luu, C. F. B. Holmes, R. J. Andersen, and S. E. Calvert. 2000. The adsorption of microcystin-LR by natural clay particles. Toxicon 38:303-308. https://doi.org/10.1016/S0041-0101(99)00149$\underline{X}$.

National Center for Biotechnology Information (NCBI). PubChem Compound Database; CID=445434, https://pubchem.ncbi.nlm.nih.gov/compound/445434 (accessed Mar. 4, 2019).

Pawlik-Skowronska, B., R. Kornijow, and J. Pirszel. 2010. Sedimentary imprint of cyanobacterial blooms - a new tool for insight into recent history of lakes.Polish Journal of Ecology 58(4):663-670.

Peuthert, A., S. Chakrabarti, and S. Pflugmacher. 2007. Uptake of Microcystins-LR and -LF (Cyanobacterial toxins) in seedlings of several important agricultural plant species and the correlation with cellular damage (Lipid peroxidation). Environmental Toxicology 22(4):436-442. https://doi.org/10.1002/tox.20266.

Pflugmacher S, Hofmann J,H“" ubner B. 2007. Effects on growth and physiological parameters in wheat (Triticum aestivum L.) grown in soil and irrigated with cyanobacterial toxin contaminated water. Environmental Toxicology and Chemistry 26(12):2710-16. https://doi.org/10.1897/07-145.1.

Richer, R., S. A. Banack, J. S. Metcalf, and P. A. Cox. 2015. The persistence of cyanobacterial toxins in desert soils. Journal of Arid Environments. 112:134-139. https://doi.org/10.1016/j.jaridenv.2014.01.023.

Rivasseau, C. S., S. Martins, and M. C. Hennion. 1998. Determination of some physiochemical parameters of microcystins (cyanobacterial toxins) and trace level analysis in environmental samples using liquid chromatography. Journal of Chromatography. 799:155-169. https://doi.org/10.1016/S0021-9673(97)01095-9.

Schmidt, J. R., S. W. Wilhelm, and G. L. Boyer. 2014. The fate of microcystins in the environment and challenges for monitoring. Toxins 6(12):3354-3387. https://doi.org/10.3390/toxins6123354.

Song, H., L. X. Coggins, E. S. Reichwaldt, and A. Ghadouani. 2015. The importance of lake sediments as a pathway for microcystin dynamics in shallow eutrophic lakes. Toxins 7(3):900-918. https://doi.org/10.3390/toxins7030900.

Stewart, I., P. Schluter, and G. Shaw. 2006. Cyanobacterial lipopolysaccharides and human health - a review. Environmental Health. 5: 7. https://doi.org/10.1186/1476-069X-5-7.

Torokne, A., A. Palovics, and M. Bankine. 2001. Allergenic (sensitization, skin and eye irritation) effects of freshwater cyanobacteria-Experimental evidence. Environmental Toxicology 16:512-516. 
ERDC/TN DOTS-20-1

January 2020

Revised July 2021

https://doi.org/10.1002/tox.10011.

Toxicology Literature Online (TOXLINE) 2018. Toxicology data network, national institute of health. Retrieved on 3 January 2018: http://toxnet.nlm.nih.gov/cgi-bin/sis/htmlgen?TOXLINE.

United States Environmental Protection Agency (USEPA). 2015a. Drinking Water Health Advisory for the Cyanobacterial Microcystin Toxins. EPA- 820R15100. Washington, DC: Office of Water.

United States Environmental Protection Agency (USEPA). 2015b. Health Effects Support Document for Cyanobacterial Toxin Microcystins. EPA-820R15102. Washington, DC: Office of Water.

Wannemacher, R. W. 1989. Chemical Stability Laboratory Safety of Naturally Occurring Toxins. Fort Detrick, Maryland: U.S. Army Medical Research, Institute of Infection Diseases.

Welker, M., and C. Steinberg C. 2000. Rates of humic substance photosensitized degradation of microcystin-LR in natural waters. Environmental Science and Technology 34(16):3415-3419.

Wood, S. A., and D. R. Dietrich. 2011. Quantitative assessment of aerosolized cyanobacterial toxins at two New Zealand lakes. Journal of Environmental Monitoring 13(6):1617-1624.

World Health Organization (WHO). 2003a. Guidelines for safe recreational water environments. Volume 1: Coastal and Fresh Waters. Geneva Switzerland: World Health Organization.

World Health Organization (WHO). 2003b. Cyanobacterial Toxins: Microcystin-LR in Drinking Water. Background Document for preparation of WHO Guidelines for drinking water quality. Geneva Switzerland: World Health Organization. https://www.who.int/water_sanitation_health/dwq/chemicals/cyanobactoxins.pdf

(WHO/SED/WSH/0.04/57).

Wormer, L., M. Huerta-Fontela, S. Cires, D. Carrasco, and A. Quesada. 2010. Natural photodegradation of the cyanobacterial toxins microcystin and cylindrospermopsin. Environmental Science and Technology 44:30023007.

Wu, X., B. Xiao, R. Li, C. Wang, J. Huang, and Z. Wang. 2011. Mechanisms and factors affecting sorption of microcystins onto natural sediments. Environmental Science and Technology 45:2641-2647.

Yang, Z., F. Kong, and M. Zhang. 2016. Groundwater contamination by microcystin from toxic cyanobacteria blooms in Lake Chaohu, China. Environmental Monitoring and Assessment 188:280.

Zastepa, A., F. R. Pick, and J. M. Blais. 2017. Distribution and flux of microcystin congeners in lake sediments. Lake and Reservoir Management 33(4):444-451. https://doi.org/10.1080/10402381.2017.1362491.

NOTE: The contents of this technical note are not to be used for advertising, publication, or promotional purposes. Citation of trade names does not constitute an official endorsement or approval of the use of such products. 